\title{
THE DEFLOCCULATING ENZYME PRODUCED BY A FLOC-FORMING BACTERIUM
}

\author{
YOSHITAKA TAGO AND KÔ AIDA \\ Institute of Applied Microbiology, The University of Tokyo, Tokyo
}

(Received June 3, 1975)

The bacterium strain No. 12 isolated from a phenol-adapted activated sludge as a floc-forming bacterium was found to produce an exoenzyme which could deflocculate its own floc. As the floc of this bacterium was not deflocculated with EDTA and various enzymes such as cellulase, protease, and lysozyme, this exoenzyme was isolated and purified. The optimal $\mathrm{pH}$ of the enzyme for deflocculation was 3.8 to 5.0, and the optimal temperature $30^{\circ}$. The enzyme was unstable at a high temperature, and heating at $45^{\circ}$ for $5 \mathrm{~min}$ resulted in complete loss of the activity. The activity of the enzyme was inhibited by a relatively low concentration of salts, acidic and basic amino acids, uronic acids, and amino sugars. Purified preparation of this enzyme released sugars from the No. $12 \mathrm{floc}$ during deflocculation, though it could not hydrolyze cellulose, pectin, and ethylene glycol chitin. These results indicate that the No. $12 \mathrm{floc}$ is composed of some exopolysaccharides other than those so far reported and deflocculated only by the enzyme produced by the bacterium itself.

Bacteria in activated sludge usually aggregate with each other (1) and this process is called floc-formation. The floc-formation is an integral part of activated sludge process. Sometimes normal activated sludge appears to break up into dispersed growth and the supernatant becomes extremely turbid (2). This phenomenon is called deflocculation. The deflocculation problems are closely related to the floc-formation mechanisms. Many investigators have attempted to elucidate the mechanisms of floc-formation in activated sludge process. A hypothesis that exopolymeric materials are responsible for the floc-forming properties of activated sludge was broadly supported (3-5).

Recently, Friedman et al. (6) and DeINEMA and Zevenhuizen (7) reported that many bacteria were found to give flocculent growth due to the formation of cellulose fibrils and these flocs were deflocculated by the treatment with cellulase. Kato et al. (8) also reported the formation of flocs by certain bacteria and their deflocculation by cellulase, pectinase, or protease with no effect on bacterial growth. 
Natural floc of activated sludge, however, could not entirely be deflocculated by treatment with the above enzymes or EDTA (9). Therefore, some other exopolymer unsusceptible to these enzymes may contribute to the floc-formation in natural activated sludge.

The present paper deals with a cellulase- and protease-unsusceptible flocforming bacterium isolated from natural activated sludge and its production of an enzyme which shows the activity of deflocculating its own floc.

\section{MATERIALS AND METHODS}

Organism. The bacterium strain No. 12 isolated from a phenol-adapted activated sludge (10) was used throughout this work. This strain is a good flocformer, gram-negative, rods with rounded ends, $0.8-0.9 \times 1.0-2.5 \mu \mathrm{m}$, occurring singly or in pairs, motile with a polar flagellum, and does not form endospores. Deflocculating enzyme was isolated from the culture fluid of this organism.

Cultivation conditions. The medium containing $15 \mathrm{~g}$ peptone, $1.0 \mathrm{~g} \mathrm{~K}_{2} \mathrm{HPO}_{4}$, $0.5 \mathrm{~g}\left(\mathrm{NH}_{4}\right)_{2} \mathrm{SO}_{4}, 0.2 \mathrm{~g} \mathrm{MgSO}_{4} \cdot 7 \mathrm{H}_{2} \mathrm{O}, 0.1 \mathrm{~g} \mathrm{CaCl}_{2} \cdot 2 \mathrm{H}_{2} \mathrm{O}$, and $0.02 \mathrm{~g} \mathrm{FeCl}_{3} \cdot 6 \mathrm{H}_{2} \mathrm{O}$ per liter, $\mathrm{pH} 7.0$, was used for the formation of the No. 12 floc and deflocculating enzyme. Ten $\mathrm{ml}$ of the 3-day culture of this strain No. 12 was inoculated into 1 liter of the same medium in a 5 -liter flask and incubated on a rotary shaker at $20^{\circ}$ for 5 days.

Preparation of No. 12 floc. The 5-day culture of this strain No. 12 was kept still for 30 min and the settled mass was washed several times with deionized cold water by decantation. This "native" floc was lyophilized and stocked in a desiccator.

Assay of deflocculating activity. The lyophilized floc was suspended in water, heated at $50^{\circ}$ for $10 \mathrm{~min}$, washed twice with deionized cold water by decantation, and resuspended in water to the concentration of $4 \mathrm{mg} / \mathrm{ml}$. Deflocculation reactions were carried out with $0.5 \mathrm{ml}$ of this suspension and $1 \mu \mathrm{g}$ of the purified enzyme protein in $1.0 \mathrm{ml}$ of acetate buffer (final concentration of $0.01 \mathrm{M}$ ), at $30^{\circ}$ for $30 \mathrm{~min}$. The reaction was stopped by the addition of $4.0 \mathrm{ml}$ of $1 \mathrm{M} \mathrm{NaCl}$ solution and the residual floc was removed with a filter paper (Toppan Shoji Co., No. 2). Increase of turbidity in the filtrate was measured at $660 \mathrm{~nm}$ by a Shimadzu QR-50 photometer. A "unit" of deflocculating activity expresses the amount of the enzyme for a complete deflocculation of $0.2 \mathrm{mg}$ of floc in $30 \mathrm{~min}$.

Chemical analysis. Protein content was determined by the method of LOWRY et al. (11) or by measuring the absorbancy at $280 \mathrm{~nm}$ with a Shimadzu QR-50 photometer. Total sugar was determined by the method of DuBOIS et al. (12).

Chemicals. CM-Sephadex C-50 and Sephadex G-100 were the products of Pharmacia, Uppsala. Meicelase P was obtained from Meiji Seika Co., Kawasaki, Takamine cellulase from Miles Lab., Inc., Indiana, cellulase A-12-C from 
Takeda Chem. Ind., Ltd., Tokyo, pronase E from Kaken Kagaku Co., Tokyo, trypsin from Sigma Co., Mo, and lysozyme from Seikagaku Kogyo Co., Tokyo. Other chemicals were of the purest grade commercially available.

\section{RESULTS}

Deflocculating tests of No. 12 floc by various enzymes

Susceptibility of the floc of the strain No. 12 to various commercial cellulases, proteases, lysozyme, EDTA, and the culture fluid of the strain No. 12 was examined. Cellulases used here were crude and showed the activities of cellulase, pectinase, hemicellulase, protease, etc. As shown in Table 1, all of the commercial enzymes

Table 1. Deflocculation tests on No. 12 floc.

\begin{tabular}{|c|c|c|c|c|c|}
\hline Enzyme & $\begin{array}{l}\text { Concn. } \\
(\mathrm{mg} / \mathrm{ml})\end{array}$ & Buffer & $\begin{array}{l}\text { Reaction } \\
\text { period } \\
\text { (hr) }\end{array}$ & $\begin{array}{c}\text { Reaction } \\
\text { temperature } \\
\left({ }^{\circ} \mathrm{C}\right)\end{array}$ & $\begin{array}{l}\text { Defloc- } \\
\text { culation }\end{array}$ \\
\hline Meicelase P & 10 & $\begin{array}{c}0.1 \mathrm{M} \text { acetate } \\
\text { pH } 5.0\end{array}$ & 2 & 37 & - \\
\hline Takamine cellulase & 10 & " & 2 & 37 & - \\
\hline Cellulase A-12-C & 10 & " & 2 & 37 & - \\
\hline Pronase E & 6 & $\begin{array}{c}0.01 \text { м Tris- } \mathrm{HCl} \\
\text { pH } 8.0\end{array}$ & 1 & 35 & - \\
\hline Trypsin & 6 & " & 1 & 35 & - \\
\hline Lysozyme & 6 & $(+0.01$ м EDTA $)$ & 1 & 30 & - \\
\hline EDTA & 5 & deionized water & 1 & 30 & - \\
\hline $\begin{array}{l}\text { Dialyzed culture } \\
\quad \text { fluid of strain No. } 12\end{array}$ & & $\begin{array}{c}0.01 \mathrm{M} \text { acetate } \\
\mathrm{pH} 4.6\end{array}$ & 1 & 30 & $+t$ \\
\hline
\end{tabular}

Deflocculation is expressed as complete deflocculation $(++)$ and no deflocculation $(-)$.

did not deflocculate the No. 12 floc, but the dialyzed culture fluid of strain No. 12 did. This fact indicates that the No. 12 floc is different in its hydrolase susceptibility from the flocs so far reported and that the strain No.12 produces the enzyme(s) capable of deflocculating its own floc.

\section{Purification of the deflocculating enzyme}

The culture fluid (10 liters) of the bacterium strain No. 12 was centrifugated at $10,000 \times g$ for $15 \mathrm{~min}$ to remove floc and free cells. To the supernatant fluid, $\left(\mathrm{NH}_{4}\right)_{2} \mathrm{SO}_{4}$ was added to $100 \%$ saturation with mechanical stirring and the mixture was allowed to stand at $4^{\circ}$ overnight. The precipitate formed was collected by centrifugation at $10,000 \times g$ for $15 \mathrm{~min}$, dissolved in a small amount of $0.1 \mathrm{M}$ acetate buffer $(\mathrm{pH} 4.8)$, and dialyzed against the same buffer overnight at $4^{\circ}$. The dialyzed fluid was centrifuged at $10,000 \times g$ for $15 \mathrm{~min}$ to remove insoluble materials and the supernatant $(157 \mathrm{ml})$ was then applied to a column $(2.2 \times 30 \mathrm{~cm})$ of CM-Sephadex C-50 previously equilibrated with $0.1 \mathrm{M}$ acetate buffer ( $\mathrm{pH} 4.6$ ). 
The column was washed with 5 volumes of the acetate buffer and then elution began with a linear gradient of 0 to $0.5 \mathrm{M}$ of $\mathrm{NaCl}$ in the acetate buffer. Fractions

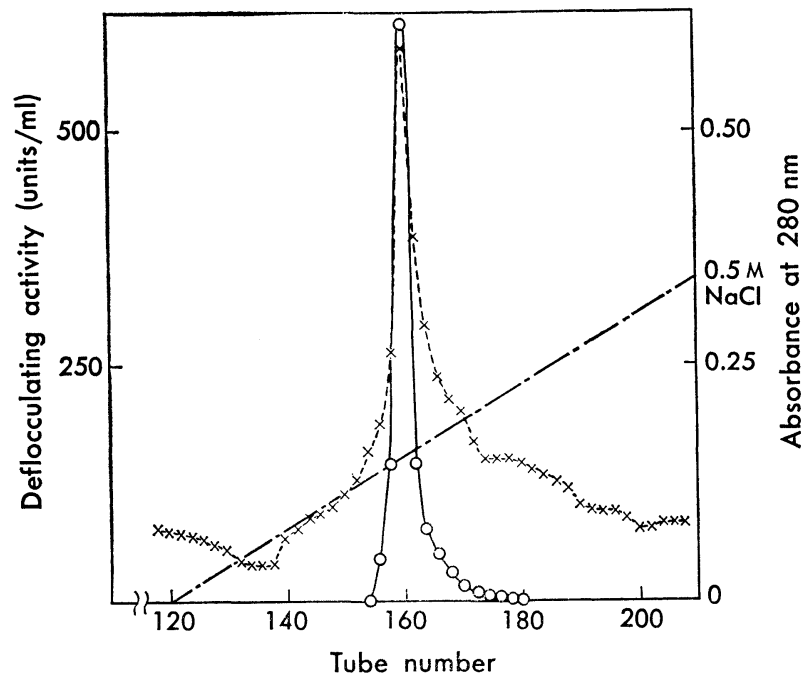

Fig. 1. CM-Sephadex C-50 chromatography of the deflocculating enzyme of strain No. 12.

- - - Deflocculating activity; --- $\times---$, Absorbance at $280 \mathrm{~nm}$.

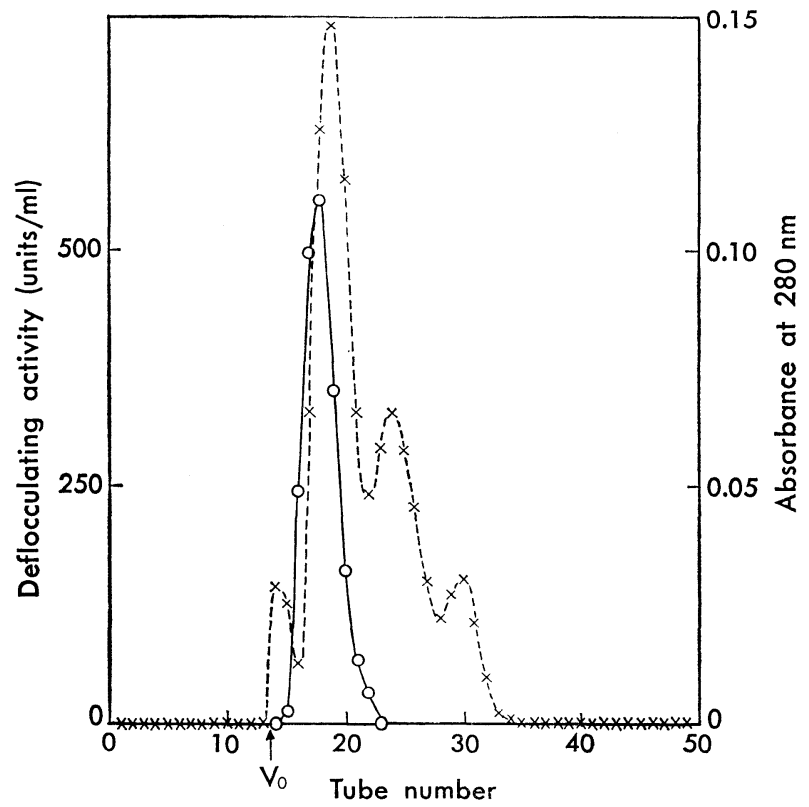

Fig. 2. Sephadex G-100 chromatography of the deflocculating enzyme of strain No. 12.

- - , Deflocculating activity; --- $\times---$, Absorbance at $280 \mathrm{~nm}$. 
of $5 \mathrm{ml}$ each were collected. As shown in Fig. 1, the deflocculating enzyme was separated from the greater part of other proteins mixed. The active fractions were combined, concentrated to $0.5 \mathrm{ml}$ in a collodion bag, and applied to a column $(1.0 \times 100 \mathrm{~cm})$ of Sephadex G-100 previously equilibrated with $0.02 \mathrm{~m}$ acetate buffer ( $\mathrm{pH} 4.6)$. The deflocculating activity flowed out from the column a little after void volume, as shown in Fig. 2. The active fractions were combined, dialyzed against $0.1 \mathrm{M}$ acetate buffer $(\mathrm{pH} 4.6)$, and then applied to a column $(1.0 \times 20 \mathrm{~cm})$ of CM-Sephadex C-50. Elution was made with $100 \mathrm{ml}$ of a linear gradient of 0 to $0.5 \mathrm{M} \mathrm{NaCl}$ in the acetate buffer and fractions of $2 \mathrm{ml}$ each were collected. Figure 3 shows the elution pattern, where a single symmetrical peak of the deflocculating enzyme is observed. Table 2 summarizes these results. Specific activity of the deflocculating enzyme increased about 2,000-fold over the culture fluid.

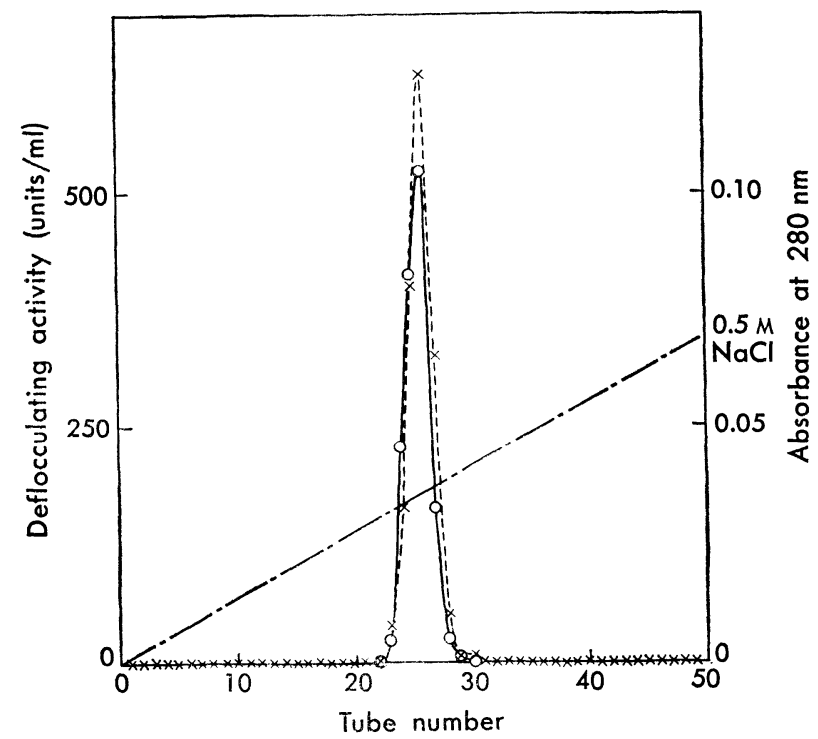

Fig. 3. Second CM-Sephadex C-50 chromatography of the deflocculating enzyme of strain No. 12.

- --, Deflocculating activity; --- $\times---$, Absorbance at $280 \mathrm{~nm}$.

Deflocculation of the No. 12 floc

Deflocculation of the No. 12 floc was examined with the purified enzyme preparation. Figure 4 shows the deflocculation of the lyophilized floc. The rate of deflocculation was proportional to the amount of the enzyme in the range of 1 to 6 units. Native floc was also deflocculated in a similar manner, without any damage on the growth activity. Release of cells from the lyophilized floc began after 10-min incubation and then proceeded linearly with incubation time. This delay of cell release may be explained by the hypothesis that the floc was first broken up by the enzyme to pieces, from which cells were released gradually. 
Table 2. Purification of deflocculating enzyme from strain No. 12.

\begin{tabular}{lccccc}
\hline \multicolumn{1}{c}{ Procedure } & $\begin{array}{c}\text { Protein } \\
(\mathrm{mg})\end{array}$ & $\begin{array}{c}\text { Deflocculating } \\
(\mathrm{U})\end{array}$ & $\begin{array}{c}\text { activity } \\
(\mathrm{U} / \mathrm{mg})\end{array}$ & $\begin{array}{c}\text { Yield } \\
(\%)\end{array}$ & $\begin{array}{c}\text { Purification } \\
\text { ratio }\end{array}$ \\
Culture fluid & 9,024 & 22,500 & 2.4 & 100 & 1 \\
CM-Sephadex C-50 (1st) & 15.4 & 11,600 & 753.2 & 52 & 299 \\
Sephadex G-100 & 1.8 & 6,800 & $3,777.8$ & 30 & 1,496 \\
CM-Sephadex C-50 (2nd) & 1.1 & 5,500 & $5,000.0$ & 24 & 2,071 \\
\hline
\end{tabular}

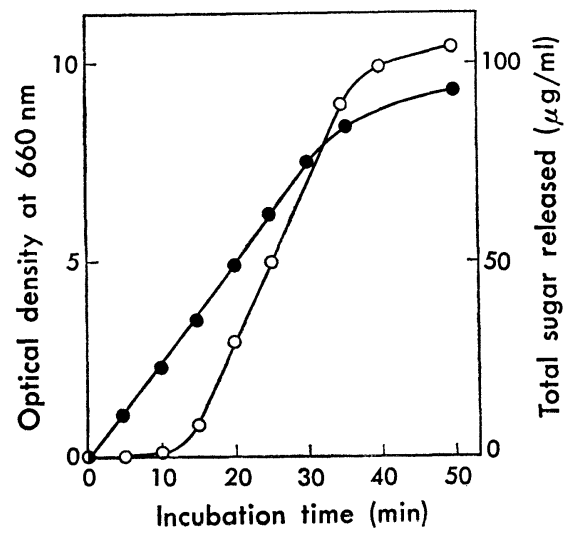

Fig. 4. Deflocculation of No. 12 floc and release of sugar from the floc by the purified deflocculating enzyme.

Reaction mixture contained $36 \mathrm{mg}$ of the lyophilized No. 12 floc and 40 units of deflocculating enzyme activity in $2 \mathrm{ml}$ of $0.01 \mathrm{~m}$ acetate buffer $(\mathrm{pH} 4.6)$. - -,$- \mathrm{OD}_{660}$ of the supernatant; - - - Total sugar in the supernatant (as glucose).

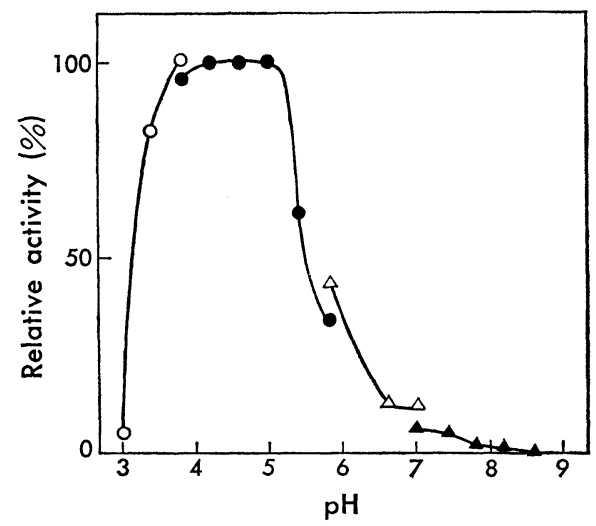

Fig. 5. Effect of $\mathrm{pH}$ on the deflocculating enzyme activity.

Each assay mixture containing 5 units of deflocculating enzyme activity. - $\mathrm{O}-$, Formate buffer, $\mu=0.01 ;-\bullet$, Acetate buffer, $\mu=0.01 ;-\triangle-$, Phosphate buffer, $\mu=$ $0.01 ;-\Lambda$ - Tris buffer, $\mu=0.01$. 
Concurrently with this cell release, an increase of sugar in the supernatant of the reaction mixture was observed. The amount of total sugar in the supernatant was proportional to the incubation time. Because of the lack of the activity to hydrolyze cellulose, pectin, and ethylene glycol chitin in the enzyme preparation used, the sugar released from the floc will not be the product of the hydrolysis of these compounds.

\section{Properties of the purified deflocculating enzyme}

Properties of the purified enzyme preparation were investigated with regard to the activity of deflocculating the lyophilized No. 12 floc. The optimal pH for deflocculation was found to be 3.8 to 5.0 (Fig. 5). The enzyme was unstable at temperatures higher than $35^{\circ}$, and heating at $45^{\circ}$ for 5 min resulted in the complete loss of the activity (Fig. 6). As shown in Fig. 7, the optimal temperature was

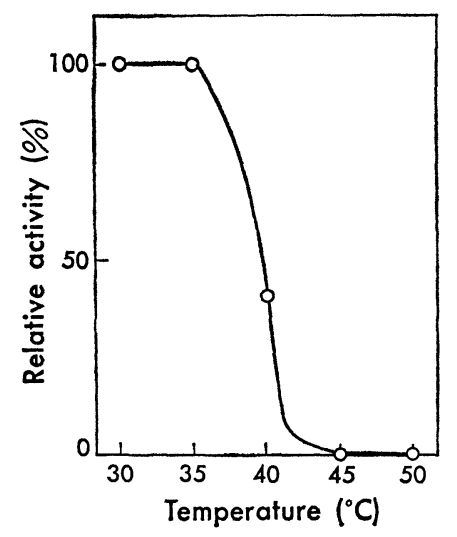

Fig. 6. Effect of temperature on the deflocculating enzyme activity.

Each assay mixture contained 5 units of deflocculating enzyme activity.

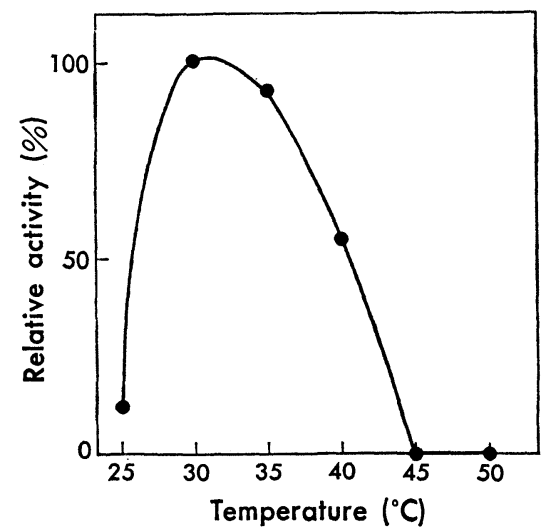

Fig. 7. Thermal stability of the purified deflocculating enzyme.

Each enzyme preparation contained 5 units of deflocculating activity was heated for $5 \mathrm{~min}$, cooled, and the remaining activity was measured. 
Table 3. Effect of various salts and EDTA on deflocculating enzyme activity.

\begin{tabular}{lcc}
\hline Salt added & $\begin{array}{c}\text { Concentration } \\
(\mathrm{mM})\end{array}$ & $\begin{array}{c}\text { Deflocculating } \\
\text { activity }(\%)\end{array}$ \\
\hline $\mathrm{None}$ & - & 100 \\
$\mathrm{NaCl}$ & 5 & 15 \\
$\mathrm{KCl}$ & 5 & 44 \\
$\mathrm{MgCl}_{2}$ & 2 & 4 \\
$\mathrm{CaCl}_{2}$ & 2 & 7 \\
$\left(\mathrm{NH}_{4}\right)_{2} \mathrm{SO}_{4}$ & 2 & 45 \\
$\mathrm{EDTA}$ & 2 & 20 \\
\hline
\end{tabular}

Each assay mixture contained 5 units of deflocculating enzyme activity.

Table 4. Effect of amino acids on deflocculating enzyme activity.

\begin{tabular}{lcclcc}
\hline \multicolumn{1}{c}{ Amino acid } & $\begin{array}{c}\text { Concn. } \\
(\mathrm{mM})\end{array}$ & Inhibition & \multicolumn{1}{c}{ Amino acid } & $\begin{array}{c}\text { Concn. } \\
(\mathrm{mm})\end{array}$ & Inhibition \\
\hline L-Glycine & 10 & - & L-Methionine & 10 & - \\
L-Alanine & 10 & - & L-Phenylalanine & 10 & - \\
L-Valine & 10 & - & L-Proline & 10 & - \\
L-Leucine & 10 & - & L-Tryptophan & 10 & - \\
L-Isoleucine & 10 & - & L-Asparagine & 10 & + \\
& & & & 1 & - \\
D,L-Serine & 10 & - & L-Histidine & 10 & + \\
& 10 & & L-Lysine & 1 & - \\
L-Threonine & 10 & - & L-Arginine & 10 & + \\
& & & & 1 & - \\
L-Cysteine & & & & 1 \\
& & &
\end{tabular}

Each assay mixture contained 5 units of deflocculating enzyme activity.

Table 5. Effect of various sugars on deflocculating enzyme activity.

\begin{tabular}{|c|c|c|c|c|c|}
\hline Sugar & $\begin{array}{c}\text { Concn. } \\
\text { (mM) }\end{array}$ & Inhibition & Sugar & $\begin{array}{c}\text { Concn. } \\
\text { (mM) }\end{array}$ & Inhibition \\
\hline Arabinose & 10 & - & Lactose & 10 & - \\
\hline Xylose & 10 & - & Saccharose & 10 & - \\
\hline Glucose & 10 & - & Maltose & 10 & - \\
\hline Galactose & 10 & - & Raffinose & 10 & - \\
\hline Mannose & 10 & - & Cellobiose & 10 & - \\
\hline Fructose & 10 & - & Trehalose & 10 & - \\
\hline Sorbose & 10 & - & Melibiose & 10 & - \\
\hline Rhamnose & 10 & - & Glucosamine & $\begin{array}{r}10 \\
1\end{array}$ & $\begin{array}{l}+ \\
+\end{array}$ \\
\hline Fucose & 10 & - & Galactosamine & $\begin{array}{r}10 \\
1\end{array}$ & \pm \\
\hline $\begin{array}{l}\text { N-Acetyl- } \\
\text { glucosamine }\end{array}$ & 10 & - & Mannosamine & $\begin{array}{r}10 \\
1\end{array}$ & \pm \\
\hline $\begin{array}{l}\text { N-Acetyl- } \\
\text { galactosamine }\end{array}$ & 10 & - & Glucuronic acid & $\begin{array}{r}10 \\
1\end{array}$ & + \\
\hline $\begin{array}{l}\text { N-Acetyl- } \\
\text { mannosamine }\end{array}$ & 10 & - & Galacturonic acid & $\begin{array}{r}10 \\
1\end{array}$ & + \\
\hline
\end{tabular}

Each assay mixture contained 5 units of deflocculating enzyme activity. 
at $30^{\circ}$. The activity was effectively inhibited with $5 \mathrm{~mm}$ of $\mathrm{NaCl}$ or $\mathrm{KCl}$, or $2 \mathrm{~mm}$ of $\mathrm{MgCl}_{2}, \mathrm{CaCl}_{2}$, or $\left(\mathrm{NH}_{4}\right)_{2} \mathrm{SO}_{4}$, as shown in Table 3. Irrespective of the kind of the buffer used, the activity was inhibited at the ionic strength $(\mu)$ higher than 0.01 . Basic or acidic amino acids such as L-Histidine, L-Arginine, L-Lysine, and L-Asparagine inhibited the enzyme activity at the concentration of $10 \mathrm{~mm}$, while no inhibition was observed at the concentration of $1 \mathrm{~mm}$, as shown in Table 4 . The activity was also inhibited by $10 \mathrm{~mm}$ of amino sugars and uronic acids, as shown in Table 5 . Glucosamine effectively inhibited the activity at the concentration of $1 \mathrm{~mm}$, but others did not.

\section{DISCUSSION}

The bacterium strain No. 12 is a good floc-former, and its culture consists of more than $90 \%$ of flocculated cells and a little of free cells $(10)$. The present paper shows that the No. 12 floc was different from the flocs so far reported (6-9), being not deflocculated by treatment with various cellulases, proteases, lysozyme, and EDTA. The present experiments also showed that the strain No. 12 produced an exoenzyme which powerfully degrades its own floc. Purified preparation of this enzyme released sugars from the No. 12 floc during deflocculation, though it could not hydrolyze cellulose, pectin, or ethylene glycol chitin. These results indicate that the No. 12 floc is composed of some exopolysaccharides other than those so far reported and is deflocculated only by the enzyme produced by itself. The isolation and properties of these exopolysaccharides will be reported later.

The life of the No. 12 floc is determined by the activity of the polysaccharidesynthesizing enzyme and its own deflocculating enzyme. The activity of the latter enzyme was the highest in the $\mathrm{pH}$ range of 3.8 to 5.0 and less than $10 \%$ was observed at $\mathrm{pH} 7.0$ which was the usual condition for floc cultivation. The No. 12 deflocculating enzyme was inhibited by relatively low concentration of salts, acidic and basic amino acids, uronic acids, and amino sugars.

Concerning the mechanism of deflocculation of activated sludge, the balance of the exopolymer-synthesizing activity of floc-forming microorganisms and exopolymer-degrading activity must be considered. Deflocculation will be the result of the hydrolysis of the exopolymers exceeding their synthesis. The exopolymerdegrading enzymes may be produced by floc-formers themselves or by other microorganisms in the activated sludge. The present report will give one example of the possibility that in some cases the deflocculation might occur due to the action of an exopolymer-degrading enzyme produced by the floc-former itself. Environmental or internal conditions affecting the synthesis or activity of the deflocculating enzyme must be further clarified. 


\section{REFERENCES}

I) W. O. PIPES, Adv. Appl. Microbiol., 8, 77 (1966).

2) W. O. Pipes, Adv. Appl. Microbiol., 9, 185 (1967).

3) M. W. Tenney and W. Stumm, J. Water Pollut. Control Fed., 37, 1370 (1965).

4) J. L. Pavani, M. W. Tenney and W. F. Echelberger, J. Water Pollut. Control Fed., 44, 414 (1972).

5) R. H. Harris and R. Mitchell, Ann. Rev. Microbiol., 27, 27 (1973).

6) B. A. Friedman, P. R. Dugan, R. M. Pfister, and C. C. Remsen, J. Bacteriol., 98, 1328 (1969).

7) M. H. Deinema and L. P. T. M. Zevenhuizen, Arch. Microbiol., 78, 42 (1971).

8) A. Kato, K. Izaki, and H. Takahashi, J. Gen. Appl. Microbiol., 17, 439 (1971).

9) Y. Tezuka, Appl. Microbiol., 17, 222 (1969).

10) Y. Tago, H. Kuraishi, and K. Aida, J. Gen. Appl. Microbiol., 21, 41 (1975).

11) O. H. Lowry, N. J. Rosebrough, A. L. Farr, and R. J. Randall, J. Biol. Chem., 193, 265 (1951).

12) M. Dubois, K. A. Gilles, J. K. Hamilton, P. A. Rebers, and F. Smith, Nature, 168, 107 (1951). 